\title{
Risk Analysis in Sugarcane Production: Evidences from Uttar Pradesh and Maharashtra States of India
}

\author{
Ajay Kumar* and Rakesh Singh \\ Department of Agricultural Economics, Institute of Agricultural Sciences, B.H.U., \\ Varanasi-221005, India \\ *Corresponding author
}

\section{A B S T R A C T}

Agriculture is an intrinsically risk industry. Sugarcane crop is grown as a important cash crop in all over the world and facing several risks in production

Keywords

Area, Production,

Yield, Sugarcane,

Price risk.

Article Info

Accepted:

17 July 2017

Available Online:

10 September 2017 and marketing. Present study focuses on the measurement of farm risk i.e. area, production, productivity and price for sugarcane production in Uttar Pradesh and Maharashtra. Coefficients of variation (CV) are used to analyze the production risk for both states. Result revealed that coefficients of variation by standard deviation (SD) of area in Uttar Pradesh were 4.92 per cent and in Maharashtra 32.82 per cent. Production risk was lower in Uttar Pradesh $(7.85 \%)$ as compared to Maharashtra $(36.89 \%)$. Productivity risk in Uttar Pradesh and Maharashtra were 4.49 and 10.04 per cent respectively. Price risk showed high in both state Uttar Pradesh and Maharashtra with 45.59 and 49.55 per cent respectively. Therefore, it can be concluded that risk associated with area, production, productivity and price risk in Uttar Pradesh was lower as compared to Maharashtra.

\section{Introduction}

Sugarcane crop is important cash crop of India and it's grown on area of more than one million hectares. The sugarcane crop is beset with many problems one abysmally low productivity leading to yearly fluctuation in production, and secondly monopolistic exploitation of sugarcane growers by the powerful sugar syndicate. Variability of crop revenues is a primary source of business risk for a farm, comprised of fluctuating components, the most important of which are area, production, productivity and prices. The risks in these components arise from different sources: productivity is dependent on weather and other external factors, and market prices are affected by supply and demand in world markets. Productivity risk varies regionally and depends on soil type, climate, the use of irrigation, etc. In contrast, price risk for a given crop depends on such factors as stock levels, supply and export demand. Risk and uncertainty are inescapable factors in agriculture. The uncertainties of weather, yields, prices, government policies, global markets, and other factors can cause wide swings in agricultural income. Price or market risk refers to uncertainty about the prices producers will receive for commodities or the 
prices they must pay for inputs. The nature of price risk varies significantly from commodity to commodity.

The market risks result from fluctuations in the prices of inputs and outputs, outside competition, changing supply and demand, market imperfections, changing consumer preferences, etc. Sale of farm produce under distress may take place due to lack of postharvest processing and lack of infrastructure storage facilities.

Weather is an important production factor in agriculture that can hardly be controlled; for example, drought or excess rain can cause poor harvests. Hence, weather risks are a major source of uncertainty in agriculture, exerting the most obvious impact on crop yields. The problem of farm income instability, affected by different sources of risks, has been raised in different contexts, such as in policy documents, scientific and applied studies. Productivity and commodity prices are important factors that determine farmers' income.

Productivity depends on natural conditions, such as climate, rainfall, soils, etc., which vary regionally. Prices are (often assumed to be) the same for all farms, however prices vary both within a single year, and across the years. This paper is mainly confined to analyze production risks viz. area, production, productivity and price risk for sugarcane production in Uttar Pradesh and Maharashtra.

\section{Materials and Methods}

The present study focuses on the measurement of farm (area, production, productivity and price) risks in sugarcane production in Uttar Pradesh and Maharashtra. For the analysis, time series (yearly) data on area, production, productivity and prices pertaining to period 2000-01 to 2014-15. The data was obtained from the database of
Department of Agricultural Cooperation and Farmers Welfare, Government of India, Directorate of Economics and Statistic in Uttar Pradesh, Sugar commissionerate, Maharashtra state, Pune. In order to analyze the farm risks descriptive statistics and coefficients of variation (CV) by range, standard deviation and mean deviation was calculated by following formula:

Range $=X_{1}-X_{2}$

Where,

$X_{1}=$ minimum value

$X_{2}=$ maximum value

Standard deviation $\left.(\mathrm{SD})=\sqrt{\frac{1}{n} \sum_{i=1}^{n}\left(X_{i}\right.}-\bar{X}\right)^{2}$

Mean deviation $(\mathrm{MD})=\frac{1}{n} \sum_{i=1}^{n}\left|X_{i}-\bar{X}\right|$

Where, $X_{i}$ is the value of $i^{\text {th }}$ individual $\bar{X}$ is the mean value, $\mathrm{i}=1,2,3 \ldots . . \mathrm{n}$ ( $\mathrm{n}$ is the number of observation)

Coefficient of variation by range $=\frac{\text { range }}{x} \times$ 100

Coefficient of variation by range $\mathrm{SD}=\frac{S D}{\bar{I}} \times$ 100

Coefficient of variation by range $\mathrm{MD}=\frac{M D}{I} \times$ 100

\section{Results and Discussion}

The main threats' facing the farmer was area, production, yield and price risks (Kimura et al., 2010). Sugarcane cultivation area in Uttar Pradesh is higher than Maharashtra as depicted in table 1. Average cultivation area of sugarcane in Uttar Pradesh and 
Maharashtra were 2113.63 and 772.33 thousand hectare respectively for the period 2000-01 to 2014-15. Area in Uttar Pradesh had lower deviation as compared to area in Maharashtra.

Similarly all the deviation of area in Uttar Pradesh was lower than Maharashtra. Result revealed that Coefficient of variation by SD of area in Uttar Pradesh was 4.92 per cent and in Maharashtra was 32.82 per cent. From the result it can be say that risk associated with area of sugarcane in Uttar Pradesh is significantly lower than Maharashtra.

It is evident from table 2 that the sugarcane production in Uttar Pradesh is higher than Maharashtra. Average production of sugarcane in Uttar Pradesh and Maharashtra were 122780.1 and 60747.05 thousand tonnes respectively for the period 2000-01 to 201415. Similar result showed in case of production also with lower deviation in Uttar Pradesh has compared to Maharashtra. There was highly difference in all coefficient of variation between Uttar Pradesh and Maharashtra. From the table production coefficient of variation by SD in Uttar Pradesh and Maharashtra are 7.85 and 36.89 per cent respectively. From the result it can be calculated that there is high risk in sugarcane production in Maharashtra.

Table 3 indicates that the sugarcane productivity in Maharashtra is higher than Uttar Pradesh. Average yield of sugarcane in Maharashtra and Uttar Pradesh are 772.48 and 580.43 quintal per hector respectively from 2000-01 to 2014-15. In case of productivity similar result were obtained as area and production. In Uttar Pradesh there was less productivity deviation as compared to Maharashtra. Result revealed that productivity coefficient of Variation in Uttar Pradesh was slightly lower than Maharashtra. Productivity coefficient of variation by SD in Uttar Pradesh and Maharashtra were 4.49 and 10.04 per cent respectively. From the result inference can be drawn that risk associated with productivity is low for both the states.

Table.1 Area variation of sugarcane in Uttar Pradesh and Maharashtra from 2000-01 to 2014- 15

\begin{tabular}{|c|c|c|}
\hline Particulars & $\begin{array}{c}\text { Area in Uttar Pradesh } \\
\text { (000 ha) }\end{array}$ & $\begin{array}{c}\text { Area in Maharashtra } \\
(000 \text { ha })\end{array}$ \\
\hline Maximum & 2246.5 & 1093 \\
\hline Minimum & 1938.4 & 324 \\
\hline Mean & 2113.63 & 772.33 \\
\hline Range & 308.1 & 769 \\
\hline Standard deviation (SD) & 104.17 & 253.55 \\
\hline Mean deviation (MD) & 88.34 & 218.75 \\
\hline Number of observations & 15 & 15 \\
\hline Coefficient of Variation by range (\%) & 14.57 & 99.56 \\
\hline Coefficient of Variation by SD (\%) & 4.92 & 32.82 \\
\hline Coefficient of Variation by MD (\%) & 4.17 & 28.32 \\
\hline
\end{tabular}


Table.2 Production variation of sugarcane in Uttar Pradesh and Maharashtra from 2000-01 to 2014-15

\begin{tabular}{|l|c|c|}
\hline Particulars & $\begin{array}{c}\text { Production in Uttar } \\
\text { Pradesh (000 Tonnes) }\end{array}$ & $\begin{array}{c}\text { Production in } \\
\text { Maharashtra (000 Tonnes) }\end{array}$ \\
\hline Maximum & 138481 & 88437 \\
\hline Minimum & 106067.5 & 20475 \\
\hline Mean & 122780.1 & 60747.05 \\
\hline Range & 32413.5 & 67962 \\
\hline Standard deviation (SD) & 9641.93 & 22413.79 \\
\hline Mean deviation (MD) & 7872.08 & 18964.74 \\
\hline Number of observations & 15 & 15 \\
\hline Coefficient of Variation by range (\%) & 26.39 & 111.87 \\
\hline Coefficient of Variation by SD (\%) & 7.85 & 36.89 \\
\hline Coefficient of Variation by MD (\%) & 6.41 & 31.21 \\
\hline
\end{tabular}

Table.3 Yield variation of sugarcane in Uttar Pradesh and Maharashtra from 2000-01 to 2014-15

\begin{tabular}{|l|c|c|}
\hline Particulars & $\begin{array}{c}\text { Productivity in Uttar } \\
\text { Pradesh (Q/Ha) }\end{array}$ & $\begin{array}{c}\text { Productivity in } \\
\text { Maharashtra (Q/Ha) }\end{array}$ \\
\hline Maximum & 621.55 & 848.66 \\
\hline Minimum & 523.26 & 579.41 \\
\hline Mean & 580.43 & 772.48 \\
\hline Range & 98.29 & 269.25 \\
\hline Standard deviation (SD) & 26.07 & 77.61 \\
\hline Mean deviation (MD) & 20.69 & 54.92 \\
\hline Number of observations & 15 & 15 \\
\hline Coefficient of Variation range (\%) & 16.93 & 34.85 \\
\hline Coefficient of Variation by SD (\%) & 4.49 & 10.04 \\
\hline Coefficient of Variation by MD (\%) & 3.56 & 7.10 \\
\hline
\end{tabular}

Table.4 Price variation of sugarcane in Uttar Pradesh and Maharashtra from 2000-01 to 2014-15

\begin{tabular}{|l|c|c|}
\hline Particulars & $\begin{array}{c}\text { Sugarcane Price in } \\
\text { Uttar Pradesh (Rs./Q) }\end{array}$ & $\begin{array}{c}\text { Sugarcane Price in } \\
\text { Maharashtra (Rs./Q) }\end{array}$ \\
\hline Maximum & 280 & 232 \\
\hline Minimum & 90 & 59.5 \\
\hline Mean & 162.46 & 112 \\
\hline Range & 190 & 172.5 \\
\hline Standard deviation (SD) & 74.07 & 55.71 \\
\hline Mean deviation (MD) & 63.36 & 46.84 \\
\hline Number of observations & 15 & 15 \\
\hline Coefficient of Variation by range (\%) & 116.94 & 153.41 \\
\hline Coefficient of Variation by SD (\%) & 45.59 & 49.55 \\
\hline Coefficient of Variation by MD (\%) & 38.99 & 41.66 \\
\hline
\end{tabular}


Over the year average price of sugarcane in Uttar Pradesh is higher than Maharashtra as depicted in table 4. Average price of sugarcane for the period 2000-01 to 2014-15 in Uttar Pradesh and Maharashtra were 162.46 and 112 Rs/Q respectively. There was little deviation in price for both the states. Similarly, coefficient of variation in Uttar Pradesh was slightly lower than Maharashtra. Price coefficient of variation by $\mathrm{SD}$ is recorded high for both Uttar Pradesh and Maharashtra with 45.59 and 49.55 percent respectively.

Therefore, it can be calculated that risk associated with price is high for both states. Price risk is the risk of price decrease or increase after a production modification has been made.

Sugarcane is an important cash crop in India and grown in all season at different region of the country. Sugarcane production is affected by internal and external factors. Risks associated with sugarcane production are manly area, production, productivity and price risk. Risk associated with area of sugarcane production in Uttar Pradesh (4.92 \%) was lower than Maharashtra (32.82\%). In case of production Uttar Pradesh (7.85 \%) state showed lower risk as compared to Maharashtra (36.89\%).

Similarly, Productivity risk was found lower in Uttar Pradesh (4.94 \%) than Maharashtra (10.04\%). Price risk was more in both states Uttar Pradesh and Maharashtra with 45.59 and 49.55 per cent respectively.

Therefore, It is suggested that farmer of Uttar Pradesh may be benefited by mitigating price risk. It is recommended that State Govt. should take necessary measures to mitigate price risk in both states, which will ultimately take care of area and production stability, because productivity risk is on minimum side.

\section{References}

Antón J., Kimura, S. and Martini, R. 2011. Risk Management in Agriculture in Canada, OECD Food, Agriculture and Fisheries Working Papers, No. 40, OECD Publishing, Paris.

APCom (Agricultural Prices Commission), 2002. Support Price Policy, Reports on Sugar cane. Agricultural Prices Commission, Gov. of India.

APCom (Agricultural Prices Commission), 2003. Support Price Policy, Reports on Sugar cane, Agricultural Prices Commission, Gov. of India.

Astover, A., and Mõtte, M. 2003. Price Risks in Estonian Agriculture. Economic Science for rural development, Jelgava: Maquette - Ltd. Jelgavas tipografija, 250-254.

Barnett, B. J., Black, J. R., Hu, Y. and Skees, J. R. 2005. Is Area-Yield Insurance Competitive with Farm-Yield Insurance? Journal of Agricultural and Resource Economics 30:285-301.

Chand, Ramesh and Raju, S. S., 2007. Risk in Indian agriculture - a case of six major crops, Situation in India, 64 (7): 283-289.

El Benni, N. and Finger, R. 2012. Where is the risk? Price, yield and cost risk in Swiss crop production, International Association of Agricultural Economists (IAAE) Triennial Conference, Foz do Iguaçu, Brazil, 18- 24.

Fufa, B., and Hassan, R. M. 2003. Stochastic Maize Production Technology and Production Risk Analysis in Dadar District, East Ethiopia, Agrekon, 42 (2): 116-128.

Jadhav, A.D., 2009. Cost and revenue of sugarcane production in India: A price risk analysis, Cooperative Sugar 40: 3136.

Kimura, S., Antón, J. and LeThi, C. 2010. Farm Level Analysis of Risk and Risk 
Management Strategies and Policies: Cross Country Analysis, OECD Food, Agriculture and Fisheries Working Papers, No. 26, OECD Publishing.

Laanemets, O., Viira, A. H. and Nurmet, M. 2011. Price, Yield and Revenue Risk in Wheat Production in Estonia, Agronomy Research 9(II): 421-426.

Purdy, B.M., Langemeier, M. R. and Featherstone, A. M. 1997. Financial Performance, Risk and Specialisation, Journal of Agricultural and Applied
Economics 29, 149-161.

Raju, S.S., and Chand, Ramesh 2007. Progress and Problem in Agricultural Insurance in India, Economics and Political Weekly, May 26, pp.19051908.

Selvaraj, K.N., 2009. Risk management strategies for drought-prone rice cultivation: a case study of Tamil Nadu, India, Asian Journal of Agriculture and Development, 6(2):95123.

\section{How to cite this article:}

Ajay Kumar and Rakesh Singh. 2017. Risk Analysis in Sugarcane Production: Evidences from Uttar Pradesh and Maharashtra States of India. Int.J.Curr.Microbiol.App.Sci. 6(9): 1211-1216. doi: https://doi.org/10.20546/ijcmas.2017.609.147 